\title{
Upaya Diaspora Indonesia Di Amerika Serikat Dalam Meningkatkan Brand Awardness Melalui Food Festival ${ }^{1}$
}

\author{
Aucky Adi Kurniawan \\ Auucky.kurniawan@aiesec.net \\ Universitas Muhammadiyah Malang \\ Nurdiana Abhiyoga \\ Universitas Muhammadiyah Malang \\ Hartoni \\ Universitas Muhammadiyah Malang \\ Abstract
}

Public diplomacy is one way to enhance inter-state cooperation through non-state actors. Among them is gastro diplomacy which is part of public diplomacy to realize the ideals of the two countries. Gastro diplomacy is food diplomacy to enhance Indonesia's brand awareness. The Indonesian Culinary Festival held in New York by the Embassy of the Republic of Indonesia is a tangible proof of a major activity to increase the country's cultural-tourism consumers, the Indonesian Diaspora coffers in the United States are actors who play an active role in this festival. Indonesian traditional food is part of an increase in Indonesia's tourism economy in the hope of increasing international interaction and cooperation. This paper will analyze the concepts, practices, and cons regarding gastro diplomacy. Starting from nation branding, this paper is expected to provide an overview of the concept of gastro diplomacy.

Keywords: Non-state actors, United States, Diaspora, Gastro-diplomacy, Indones

\begin{abstract}
Abstrak
Diplomasi publik merupakan salah satu cara untuk meningkatkan kerjasama antarnegara melalui aktor non-negara. Diantaranya adalah gastro diplomasi yang menjadi bagian dari diplomasi publik untuk mewujudkan cita-cita dari kedua negara. Gastro diplomasi adalah diplomasi makanan untuk meningkatkan brand awarness Indonesia. Festival Kuliner Indonesia yang dihelat di New York oleh Kedutaan Besar Republik Indonesia menjadi bukti nyata dari kegiatan besar untuk meningkatkan konsumen pariwisata-budaya negara, pundi-pundi Diaspora Indonesia di Amerika Serikat merupakan aktor yang berperan aktif dalam festival ini. Makanan tradisional Indonesia merupakan bagian dari peningkatan ekonomi pariwisata Indonesia dengan harapan meningkatkan interaksi dan kerja sama internasional. Tulisan ini akan menganalisis konsep, praktik, dan kontra mengenai gastro diplomasi. Bermula dari nation branding, tulisan ini diharapkan dapat memberikan gambaran mengenai konsep gastro diplomasi. Kata Kunci: Aktor non-negara, Amerika Serikat, Diaspora, Gastro-diplomasi, Indonesia
\end{abstract}

\footnotetext{
${ }^{1}$ Artikel ini Juara Pertama dalam Kompetisi artikel tingkat nasional tahun 2019 dengan melibatkan tiga juri 1) Dr.Ganewati Wuryandari ( LIPI), Laode Muhamad Fathun., S.IP., M.H.I ( Dosen HI UPNVJ) ,3) Aji Said Muhamad Iqbal ( ISAFIS)
} 


\section{Pendahuluan}

Hubugan kerjasama bilateral antara Amerika Serikat dengan Indonesia telah terjalin lebih dari 50 tahun, menunjukkan Indonesia sungguh kuat dengan Amerika Serikat. Hal ini tidak dipungkiri oleh berkembangnya Industri Amerika Serikat di Indonesia, begitu pula produk Indonesia yang diekspor ke Amerika Serikat. Banyak pekerja imigran Indonesia yang bekerja sekaligus hidup di Amerika Serikat, hal ini justru membuat perkumpulan komunitas masyarakat Indonesia di Amerika Serikat. Hubungan bilateral yang telah terjalin antar negara menjadi hubungan yang semakin serius melalui hubungan antar warga negaranya. Komunitas tersebut menjadi Diaspora Indonesia di Amerika Serikat. Setidaknya terdapat lebih dari 200.000 jiwa, warga Indonesia yang berada di Amerika Serikat. Diaspora ini memiliki nama yaitu Indonesian Diaspora Network (IDN) USA. Mereka sering menjalin silaturrahmi bersama dengan warga Indonesia di Amerika Serikat dengan berbagai acara, perayaan hari raya Idul Fitri hingga festival makanan yang diadakan oleh kedutaan besar Indonesia di Amerika Serikat. Diaspora ini juga memberikan identitas bahwa Indonesia hadir di Amerika Serikat, sebagai representatif bangsa di negeri Paman Sam. Festival budaya dan makanan Indonesia yang diadakan oleh KBRI Washington juga dihadiri dan diisi oleh IDN. Beberapa kegiatan festival makanan ini memang membuat para kelompok Diaspora mengingat dan bertujuan untuk meningkatkan perekonomian Indonesia melalui pengenalan budaya tersebut. (Wicaksana, 2019)

Peran Diaspora juga turut membantu pemerintah dalam menyebarkan sekaligus mengembangkan Brand Awareness ${ }^{2}$ tentang makanan dan budaya Indonesia. Hal ini didukung oleh negara melalui festival makanan yang dihelat, kekuatan rasa yang dimiliki oleh makanan dapat terjalin antar peradaban yang berbeda. Hal ini membuat hubungan antar kedua negara semakin erat melalui makanan, hubungan antar bangsa yang berbeda (Arief, 2018). Makanan Indonesia juga mudah ditemui di New York, Los Angeles dan Washington DC. Banyak kedai maupun restauran makanan Indonesia yang menjamur di Amerika Serikat. Hal ini tak terlepas dari cita rasa

\footnotetext{
${ }^{2}$ Brand Awarness merupakan konsep dalam Kesadaran mencintai produk dalam negeri
} 
yang membuat warga Amerika Serikat jatuh cinta terhadap kuliner Indonesia.

Kuliner Indonesia yang menjadi salah satu representatif cita rasa budaya Indonesia. Makanan menjadi hal yang cukup kuat untuk menyatukan hubungan antar masyarakat, akulturasi budaya yang mmebuat hal ini kuat. Makanan menjadi dasar dari perbedaan menjadi satu dalam rasa. Peran diaspora ini juga memberikan dampak besar terhadap negara, khususnya di bidang pariwisata. Wisatawan dari Amerika Serikat yang pergi ke Indonesia juga cukup besar, salah satu alasannya ialah karena rasa otentik yang dimiliki oleh makanan Indonesia. Peran diaspora terhadap meningkatkan Brand Awareness kuliner Indonesia dalam meningkatkan ekonomi Indonesia di Amerika Serikat. Dengan demikian, artikel ini akan membahas tentang kelompok diaspora dalam gastrodiplomasi Indonesia terhadapAmerika Serikat dalam food festival?

\section{Tinjauan Pustaka}

\section{Gastrodiplomasi}

Gastrodiplomasi merupakan salah satu bagian dari public diplomasi. Gastrodiplomasi adalah salah satu cara yang digunakan oleh suatu negara dengan cara memperkenalkan budaya dan makanan khas. Kekayaan ragam makanan khas dapat menjad idaya Tarik tersendiri bagi masyarakat global. Makanan merupakan sarana komunikasi nonverbal yang sangat kuat yang dapat mengubah persepsi masyarakat global dan meningkatkan brand awareness bagi suatu negara. Bagi banyak masyarakat diseluruh dunia yang tidak bepergian keluar negeri, pendekatan kuliner dapat menjadi alternative untuk mengunjungidan mengenal sebagian dari dunia yang belum mereka ketahui melalui rasa makanan khas dari negara lain.Diplomasi ini dapat memberi gambaran mengenai budaya suatu negara dalam hal makanan, bagaimana makanan tersebut disajikan, dan dapat menjadi identitas budaya bangsa. Hal ini menjadi salah satu instrument untuk menciptakan pemahaman lintas budaya dengan harapan meningkatkan interaksi dan kerjasama internasional (Pujayanti, 2017).

Jenis Diplomasi ini juga merupakan bagian yang menerapkan aspek kebudayaan untuk menunjukan identitas suatu negara terhadap peningkatanentitas yang ada di masyarakat global dan juga merupakan perkembangan konsep baru dari Public Diplomacy yang berasakan konsep Soft Power. Jika dilihat secara historis, munculnya Gastrodiplomacy berawal dari 
Amerika Serikat yang membangun ribuan outletmakanan cepat saji Mcdonaldsecara massive pada awal tahun 1950-an. Memasuki era perkembangan restoran cepat saji inilah Gastrodiplomasi menjadi ujung tombak perkembangan zaman di era revolusi industry 4.0 (Bhardanshah, 2018)

\subsection{Diaspora}

Lahirnya diaspora ditandai dengan adanya migrasi terpaksa. Ketika voluntary migration $^{3}$ semakin banyak warga negara diseluruh dunia yang melakukan migrasi, maka tipologi diaspora akan meluas. Diaspora bukan hanya merujuk pada kelompok yang terpaksa pergi/pindah dari negara asalnya dan keturunan mereka, tetapi ini juga dimaksudkan kepada mereka yang tinggal dinegara tujuan migrasi karena suatu pilihan (sukarela) yang didasari oleh beragam alasan: pekerjaan, pendidikan, kultural, politik, dan lainnya. Migrasi tersebut permanen dan sementara (misalnya tenaga kerja yang terikat kontrak dalam jangka waktu tertentu, para diplomat dan anggota keluargamereka,pelajar/ mahasiswa). (Romdiati, 2015)

Konsep diaspora dan konsep transnasional sering dikaitkan dengan

\footnotetext{
${ }^{3}$ Migrasi sukarela. Yaitu migrasi yang dilakukan tanpa adanya keterpaksaan
}

pengamatan bahwa, ketika sampai pada pemahaman tentang politik, mobilitas manusia dapat menguatkan dan menciptakan kembali nasionalisme. Diaspora yang menetap disuatu negara juga memiliki peran yang cukup penting dalam pembangunan identitas sebuah negara. Dinamika migrasi internasional dalam volume maupun sebaran destinasi migrasi, merupakan potensi besar untuk perkembangan dan penguatan diaspora.

Diaspora dan migrasi internasional merupakan salah satu proses globalisasi dalam dimensi kultural, sosial, politik dan ekonomi. Meskipun diaspora tidak memiliki langsung dengan globalisasi, tetapi menguatnya gejala diaspora di era globalisasi tidak dapat dipungkiri. Sementara itu, bagi diaspora yang sudah terbentuk lama, globalisasi dapat memperkuat eksistensi mereka dikalangan masyarakat internasional. Contohnya adalah India dan Cina, yang merupakan bukti nyata adanya penguatan diaspora di era global, yang diindikasikan dari kontribusinya di negara asal, dimana peran tersebut tidak terlepas dari proses globalisasi, selain karena kebijakan pemerintah yang memfasilitasi peran diaspora.

Kebijakan pemerintah dalam memberikan fasilitas yang bersifat positif 
untuk kepentingan negara dapat dilakukan melalui berbagai cara. Pengalaman di negara-negara yang berhasil memanfaatkan diasporanya untuk pembangunan ekonomi, politik, maupun sosial adalah dengan diberikannya legalitas status kewarganegaraan. Dwikewarganegaraan bagi diaspora tidak hanya memberikan rasa nyaman dan aman dalam menjalani kehidupan transnasionalnya, namun negara juga manfaat dari diasporanya dapat diambil, misalnya sebagai penghubung dalam perdagangan internasional, menarik investor asing, diplomasi politik dengan negara penerima, transfer pengetahuan dan ketrampilan, dan masih banyak lagi. 
Tabel 1.1

Literature Review

\begin{tabular}{|c|c|c|c|}
\hline Nomer & $\begin{array}{c}\text { Nama Penulis dan Judul } \\
\text { Penelitian }\end{array}$ & $\begin{array}{c}\text { Metodelogi dan } \\
\text { Konsep Penelitian }\end{array}$ & Hasil Penelitian \\
\hline 1. & $\begin{array}{l}\text { umawardhana, Bhardanshah } \\
\text { ad November 2018, Polilateral } \\
\text { lomacy: Mengungkap Interaksi } \\
\text { or Dalam Aktifitas } \\
\text { lomasi Indonesia Di Los }\end{array}$ & $\begin{array}{l}\text { Konsep dari } \\
\text { Public Diplomacy } \\
\text { yang } \\
\text { berlandaskan } \\
\text { konsep Soft } \\
\text { Power yang } \\
\text { dipaparkan oleh } \\
\text { Joseph Nye } \\
\text { (2004) dalam } \\
\text { jurnal; Food } \\
\text { Studies An } \\
\text { Interdisiplinary } \\
\text { Journal } \\
\text { (Reynolds, 2012). } \\
\text { Dengan } \\
\text { menggunakan } \\
\text { metode in depth } \\
\text { interview dan } \\
\text { Kualitatif. }\end{array}$ & $\begin{array}{l}\text { Ada sekitar } 70 \\
\text { jenis masakan } \\
\text { kahs Indonesia } \\
\text { yang dihidangkan } \\
\text { dalam kegiatan } \\
\text { tersebut } \\
\text { mengingat } \\
\text { Indonesia pada } \\
\text { saat itu sudah } \\
\text { menginjak usia } 70 \\
\text { tahun setelah } \\
\text { kemerdekaan. } \\
\text { Pengusaha kuliner } \\
\text { yang merupakan } \\
\text { perwakilan dari } \\
\text { organisasi } \\
\text { Kerukunan } \\
\text { Rakyat Makassar, } \\
\text { Persatuan } \\
\text { Masyarakat } \\
\text { Manado, dan } \\
\text { Paguyuban } \\
\text { Masyarakat jawa } \\
\text { Los Angeles } \\
\text { dengan cara } \\
\text { mengundang para } \\
\text { masyarakat untuk }\end{array}$ \\
\hline
\end{tabular}




\begin{tabular}{|c|c|c|c|}
\hline & & & $\begin{array}{l}\text { hadir dalam setiap } \\
\text { acara pameran } \\
\text { kebudayaan dan } \\
\text { kuliner khas } \\
\text { Indonesia. }\end{array}$ \\
\hline 2. & $\begin{array}{l}\text { Adirini Pujayanti } 29 \text { Mei } 2017 . \\
\text { Gastrodiplomasi - Upaya } \\
\text { Memperkuat Diplomasi } \\
\text { Indonesia . }\end{array}$ & $\begin{array}{l}\text { Dengan } \\
\text { menggunakan } \\
\text { teori } \\
\text { Gastrodiplomasi } \\
\text { dan konsep } \\
\text { diplomasi public, } \\
\text { yang didukung. } \\
\text { dengan metode } \\
\text { penelitian } \\
\text { kualitatif. }\end{array}$ & $\begin{array}{l}\text { upaya } \\
\text { memperkuat } \\
\text { gastrodiplomasi } \\
\text { dengan } \\
\text { mengandalkan } \\
\text { para aktor } \\
\text { diplomasi } \\
\text { semata tanpa } \\
\text { adanya satu } \\
\text { tujuan bersama } \\
\text { yang hendak } \\
\text { dicapai dan } \\
\text { adanya instansi } \\
\text { yang akan } \\
\text { menjadi leading } \\
\text { sector akan } \\
\text { mengalami } \\
\text { banyak kendala. }\end{array}$ \\
\hline 3. & $\begin{array}{l}\text { Sarah Patrecia Sinulingga, } \\
\text { Oktober 2017. Diplomasi } \\
\text { Kebudayaan Indonesia } \\
\text { Terhadap Amerika Serikat } \\
\text { Melalui Kuliner } \\
\text { (Gastrodiplomacy) }\end{array}$ & $\begin{array}{l}\text { Dengan metode } \\
\text { penelitian data } \\
\text { berupa studi } \\
\text { literature yang } \\
\text { dilakukan dengan } \\
\text { cara menghimpun }\end{array}$ & $\begin{array}{l}\text { Festival kuliner } \\
\text { Indonesia banyak } \\
\text { mencuri perhatian } \\
\text { masyarakat } \\
\text { Amerika Serikat, } \\
\text { hal tersebut dapat }\end{array}$ \\
\hline
\end{tabular}




\begin{tabular}{|l|l|l|}
\hline Tahun 2010-2016. & data sekunder & dilihat dari jumlah \\
dalam hal ini & pengunjung yang \\
mencapai ribuan \\
diwakili oleh & informasi- & orang pada setiap \\
festival. \\
informasi dari & literatur-literatur & Keuntungan yang \\
yang relevan & terus meningkat \\
dengan masalah & setiap tahunnya \\
yang diteliti, & didapat dari hasil \\
dengan & festival yang \\
pertimbangan & diikuti. \\
& pengumpulan data \\
dalam penelitian & ini secara \\
kualitatif & \\
\end{tabular}




\section{Metode Penelitian}

Analisa data dalam penelitian ini menggunakan analisa kualitatif yaitu penelitian yang menggambarkan isi namun tidak berdasarkan akurasi statistik. Data-data yang telah terkumpul, diolah dan dianalisis sesuai permasalahan yang diteliti. Analisa kualitatif cenderung menggunakan data berupa kata-kata yang disusun dalam bentuk cerita atau peristiwa, yang memiliki kesan lebih nyata, lebih hidup, penuh makna sehingga lebih meyakinkan pembaca daripada halaman yang penuh dengan angka-angka (Silalahi, 2009). Hal ini juga dibantu oleh intrepetasi dari data yang didapatkan dengan teori dan konsep yang digunakan pada penelitian ini. Dalam mendapatkan data-data yang akan dianalisis dalam penelitian ini, untuk meneliti fenomena ini, adapun berikut teknik pengumpulan data yang akan digunakan ialah Studi Kepustakaan.

\section{Pembahasan}

\section{a. Diaspora Indonesia di Amerika Serikat}

Diaspora menjadi representatif negara Indonesia yang didukung dari latar belakang dan identitas yang sama, mereka yang berimigrasi dari negara asalnya dan membentuk kelompok dengan asal yang sama merupakan bagian dari Diaspora (Baubock \& Faist, 2010). Diaspora membentuk kelompok yang memiliki asal regional yang sama. Diaspora juga merupakan suatu contoh dari hadirnya representatif suatu negara atau bangsa. Diaspora membawa identitas dan ciri dari suatu negara melalui kehadiran mereka di suatu negara.

Diaspora Indonesia telah memiliki jaringan yang luas dan kuat. Persamaan identitas seperti asal daerah, suku, ras dan bangsa merupakan hal yang melatarbelakangi terbentuknya diaspora di suatu negara. Rasa rindu akan tanah air dapat diobati dengan bertemu para anggota diaspora dan mengobati rasa rindu tersebut tanpa pergi ke negara asal. Hal ini juga dibuktikan dengan berkomunikasi dengan kelompok atau orang yang memiliki latar belakang yang sama akan menimbulkan rasa puas dalam diri seseorang. Hal ini yang membuat kelompok diaspora membentuk perkumpulan antar kelompok ataupun perseorangan.

Budaya silaturahmi dan berkumpul dengan sekadar berbincang santai telah menjadi adat istiadat di berbagai daerah di Indonesia, hal itu 
juga yang dibawa oleh para anggota diaspora. Berkumpul-kumpul untuk sekadar makan-minum dan berbincang menjadi hal yang sederhana, hal itu juga menjadi pemersatu dari diaspora. Berkumpul dan berbagi makanan yang dibawa juga dapat mengobati kerinduan akan tanah air, makanan Indonesia juga menjadi jamuan yang sulit didapatkan di luar negeri. Hal ini justr membuat para anggota dari Diaspora cukup giat untuk menghadiri acara sedehana seperti kumpul dan silaturahmi biasa.

Diaspora Indonesia di Amerika memiliki banyak jaringan di setiap negara bagian. Diaspora Indonesia juga menjadi bagian penting dari diplomasi yang Indonesia miliki di Amerika Serikat. Diaspora Indonesia juga memiliki jaringan terstruktur melalui Indonesian Diaspora Network (IDN). Mereka yang hidup di Amerika Serikat terkoneksi melaui jaringan IDN ini, dari mencari tempat tinggal hingga pekerjaan. Diaspora Indonesia juga menjadi bagian dari diplomasi publik Indonesia secara tidak langsung. Hal ini ditengarai dengan kerjasama oleh kedua negara yang terjalin selama 70 tahun.

IDN di Amerika Serikat cukup memberikan kontribusi terhadap hubungan bilateral Amerika Serikat dan
Indonesia, hal ini ditengarai dengan hadirnya diaspora dalam setiap perayaan kerjasama ataupun kegiatan yang dilakukan oleh KBRI maupun KJRI di Amerika Serikat. IDN memberikan banyak kontribusi dalam penyebaran budaya ataupun pengetahuan tentang negara. Menteri Luar Negeri Indonesia, Retno Marsudi, juga menyatakan bahwa peran dari perwakilan RI di luar negeri juga menjadi game changer. Hal ini juga merupakan strategi kerjasama yang melibatkan reaksi people to people ${ }^{4}$ tidak hanya melalui instansi formal, hal ini disebutkan untuk meningkatkan kerjasama di bidang investasi asing, nilai ekspor dan wisatawan asing di Indonesia (Kementerian Luar Negeri Republik Indonesia, 2019).

\section{Kepentingan}

ekonomi

Indonesia menjadi tujuan dari adanya kerjasama bilateral hingga multilateral antar negara. Hal ini juga digaungkan oleh Indonesia, kerjasama ekonomi melalui diplomasi antar negara juga penting dilakukan oleh negara. Hal ini justru membuat peran diaspora secara tidak langsung menjadi agen yang berperan besar terhadap pengenalan

\footnotetext{
${ }^{4}$ People to people adalah konsep yang menjelaskan hubungan antara manusia dengan manusia lainnya, dengan melihat situasi dan reaksi dari isu yang dibahas.
} 
Indonesia di tingkat grass root ${ }^{5}$ untuk berpartisipasi ataupun mengenal Indonesia.Diaspora juga menjadi aktor yang cukup signifikan dalam melakukan sosialisasi secara tidak langsung, hubungan people to people justru lebih kuat jika hubungan antar personal yang berkaitan terjalin dengan baik.

Amerika Serikat menjadi salah satu negara adidaya yang cukup memiliki prospek tinggi terhadap kerjasama ekonomi negara Indonesia. Diaspora Indonesia di Amerika Serikat juga memiliki bisnis yang turut memperkenalkan Indonesia melalui makanan yaitu Asnur Bahar. Pria ini memiliki bisnis bumbu rendang yang akhirnya sukses menjadi distributor bumbu rendang di Amerika Serikat. Rendang and Co telah melebarkan sayapnya menjadi distributor bumbu makanan Indonesia, hal ini juga berkembang pesat sesuai dengan pangsa pasar yang membutuhkan bumbu makanan ini (liputan6.com, 2019).

b. Gastrodiplomasi: Masakan Indonesia di Amerika Serikat serta Peran Diaspora Indonesia

${ }^{5}$ Grass rootmerupakan konsep akar rumput atau bagian dari tingkat terbawah kelas sosial dalam masyarakat.
Makanan Indonesia menjadi salah satu incaran parawisatawan yang cukupmengenal Indonesia melaluimakanan yang mereka coba di negaraasal mereka. Hal inijustrumembuatmakanan Indonesia menjadi alasan parawisatawan Internasional berkunjung ke Indonesia. Tentu saja pengaruh makanan membuat para wisatawan jatuh hati akan pesona Indonesia. Hal ini masuk ke dalam peran negara dalam membuat national branding melalui makanan. Pemerintah Thailand memulai program ekspansi dan promosi makanan di tahun 2002 dengan tagline 'Taste of Thailand", dimanapemerintah Thailand cukup mengeluarkan banyak danau untuk promosi makanan tersebut. Tidak hanya Thailand negara middle power seperti Taiwan juga menggaungkan wisata budayanya melalui makanan, hal ini diharapkan untuk meningkatkan devisa negara dan ekspansi identitas nasional dari negara yang bersangkutan. Ekspansi ini diikuti pula dengan animigrasi dari Thailand ke Amerika Serikat, di New York terdapat 55 Restoran Thailand yang beroperasi hingga saat ini. Paul Rockwell, seorang ahli 
dalam diplomasi public mengatakan bahwa negara tidak apa bergerak sendiri melalui program-program pendekatan formal dengan masyarakat akan tetapi masyarakat juga harus mendapatkan pendekatan informal, yaitu individu (Quartz, 2019).

Pemerintah

Indonesia mengadakan beberapa kegiatan di Amerika Serikat melalui perwakilannya untuk turut mengambil andil dalam promosi budaya. Beberapa contoh yang dilakukan melalui acara Wonderful Indonesia, Bazaar Makanan dan Food Festival. Hal ini dikuatkan melalui pesan Menteri luar negeri Indonesia, Retno Marsudi, yang secara langsung menyampaikan pesan bahwa kepentingan ekonomi Indonesia adalah hal yang utama (Kementerian Luar Negeri Republik Indonesia, 2019). Tentus aja banyak jalan menuju China, sama halnya dalam menggapai kepentingan tersebut yaitu Dplomasi Publik.

Diplomasi public dalam hal ini mencakup beberapa hal yang sangatluas, tapi hal yang menjadi focus kajian dalam penelitian ini yaitu gastrodiplomasi. Diplomasi ini cukup berbeda dari diplomasi makanan yang dihelat secara langsung untuk menyampaikan pesan politik melalui makanan. Gastrodiplomasi cukup menyakinkan untuk dilakukan sebagai alat diplomasi secara non-formal. Kuliner Indonesia yang disajikan di beberapa festival jajanan Indonesia di Washington DC, Boston dan New York tentu menarik perhatian warga setempat, turut mengundang para Diaspora untuk berpartisipasi ataupun hanya menghadiri acara tersebut.

Diplomasi menjadi alat yang cukup kuat untuk menjalin kerjasama, khususnya hubungan antar individu. Gastrodiplomasi mengandalkan makanan untuk menjalin hubunganan antar individu untuk mencapai kepentingan yang dibutuhkan, dalam hal ini ekonomi. Diaspora menjadi aktor penting dalam melakukan diplomasi ini. IDN di Amerika Serikat sudah menjadi representative bagi negara untuk melakukan hubungan antar individu di AmerikaSerikat. Makanan Indonesia memiliki ciri khas gurih, manis, asam dan pedas, hal ini menjadi salah satu daya Tarik makanan Indonesia yang 
kaya akan rempah memiliki kekayaan rasa.

Belajar dari Thailand, ekspansi diaspora mereka di Amerika Serikat, memiliki potensi yang besar terhadap devisa negara. Sebagian besar dari imigran Thailand yang menetap maupun bekerja di Amerika Serikat, turut membuka restoran makanan Thailand untuk menjadi sumber penapatan mereka, hal tersebut tentu secara tidak langsung didukung oleh perwakilan negara mereka. Hal ini juga mungkin yang belum secara menyeluruh dilakukan oleh diaspora Indonesia. Tetapi negara dapat menjadi kunci dalam pelaksanaan dan mendukung IDN untuk membuka bisnis makanan di Amerika Serikat.

Manhattan, New York menjadi salah satu kota metropolitan yang cukup menjanjikan untuk membuka bisnis. Tetapi menurut data New York Times, hanya terdapat 5 restauran makanan Indonesia di New York. Hal ini justru berbeda dengan kuliner Thailand yang sangat mudah ditemukan, di New York sendiri restoran masakan Thailand terdapat 55 outlet. Indonesia menjadi salah satu aktor penyemangat yang cukup menyakinkan dalam pelaksanaan gastrodiplomasi. Diaspora Indonesia sebagai media penyalur kepentingan tersebut juga dapat menunjang kerjas sama antar individu, korporasi dan instansi negara.

b. Urgensi dari peran gastrodiplomasi dalam kerjasama antara Indonesia dan Amerika Serikat

Diaspora Indonesia menjadi aktor yang penting untuk meningkatkan kerjasama ekonomi melalui makanan. Diaspora Indonesia di Amerika Serikat memberikan harapan terhadap terwujudnya kerjasama ekonomi yang dimiliki oleh kedua negara. Negara memiliki komitmen untuk mendapatkan dukungan dari negaranegara yang ingin bekerjasama. Amerika Serikat juga memiliki kepentingan terhadap Indonesia. Rendang \& co. merupakan salah satu bukti bahwa kekuatan makanan dan bumbu masakan Indonesia digemari di AmerikaSerikat (liputan6.com, 2019). Hal ini justru dapat menjadi potensi bagi Indonesia untuk mengembangkan kerjasama ekonomi dalam bidang rempah-rempah atau bumbu racikan masakan Indonesia. 
Kerjasama ekonomi Indonesia dalam hal ini membutuhkan pihak ketiga yang menjadi alas an Indonesia untuk melakukan ekspor masakan dan bumbu racikan masakan Indonesia ke AmerikaSerikat. Hal ini didukung oleh besarnya jumlah imigran Indonesia di AmerikaSerikat. Tentu hal ini menjadi potensi bagi Indonesia untuk mengembangkan kesempatan ekonomi melalui kuliner Indonesia. Peran negara dalam mempromosikan budaya dan makanan Indonesia melalui bazaar dan festival sudah cukup membantu, akan tetapi dukungan dari diaspora juga jangan sampai dilupakan. Hal yang dapat meningkatkan kerjasama dengan negara Amerika Serikat ialah hadirnya diaspora dalam memperkenalkan kuliner Indonesia sdimata dunia.

Diaspora Indonesia menjadi pintu pembuka bagi para investor ataupun pembisnis yang tertarik untuk mengembangkan bisnis makanan Indonesia di Amerika Serikat. Hadirnya IDN di Amerika Serikat menjadi salah satu kunci dalam kepentingan ekonomi Indonesia yang selalu digagas untuk meningkatkan devisanegara. Kemudahan jangkauan makanan Indonesia di Amerika Serikat juga perlu ditingkatkan untuk meningkatkan devisa negara melalui makanan yang dicicipi oleh para warga lokal Amerika Serikat. Menurut data yang diberikan Kementerian Budayadan Pariwisata, devisa negara melalui pariwisata meningkat sebanyak $48,8 \%$ daritahun 2015 yang meraup sebanyak Rp 169 Triliun, hal ini justru meningkat pada tahun 2017 menjadi $\quad \mathrm{Rp} \quad 221 \quad$ Triliun (Kementerian Budaya dan Pariwisata, 2018). Faktor yang mendukung hal ini ialah, festival budaya, bazaar, dan jangkauan Indonesia di Luar Negeri. Jangkauan menjadi salah satu faktor yang cukup berpotensi. Jangkauan dapat ditingkatkan melalui relasi dari IDN dan warga lokal, hal ini juga dapat melalui makanan yang dipromosikan dari wargalokal. Makanan tradisional dan khas menjadi incaran para turis mancanegara.

\section{Kesimpulan}

Diaspora menjadi represntatif dan secara tidak langsung menjadi 
media pendukung negara dari luar negeri. Diaspora Indonesia di Amerika Serikat, bersatu membentuk organisasi IDN (Indonesian Diaspora Network) di Amerika Serikat. Jaringan ini justru digunakan untuk lebih terstruktur dan membantu hubungan antara instansi pemerintah dan diaspora lebih efektif untuk terhubung. Kerjasama yang dilakukan oleh Amerika Serikat dan Indonesia menjadi tombak dalam melakukan kegiatan diplomasi di kemudian hari. Diaspora juga menjadi salah satu alasan bagi negara untuk menjalin kerjasama dengan negara lain. Diaspora Indonesia turut mengenalkan Indonesia melalui makanan. Salah satu bukti dari Diaspora Indonesia yang mengenalkan Indonesia melalui makanan adalah Rendang\&co., Rendang\&co juga mengikuti serangkaian kerjasama dengan perwakilan RI di Amerika Serikat, seperti mengikuti food festival dan bazar. Pengenalan ini juga mendukung warga Amerika Serikat untuk mendapatkan kerjasama dengan negara Amerika Serikat. Keinginan warga negara Amerika Serikat untuk berwisata ataupun sekdar mengunjungi Indonesia, dapat dibangun dari sub-unit terkecil dalam masyarakat yaitu individu. Oleh karena itu Gastrodiplomasi dalam hal ini mendukung dilomasi Indonesia untuk menjalin kerjasama ekonomi dengan Amerika Serikat. 


\section{Referensi}

Pujayanti, A. (2017).

GASTRODIPLOMASI

- UPAYA

MEMPERKUAT

DIPLOMASI

INDONESIA. Pusat

Penelitian Badan

Keahlian DPR, 39-40.

Silalahi, U. (2009). Metode Penelitian

Sosial. Bandung.

Mestika, Z. (2004). Metode Penelitian

Kepustakaan. Jakarta:

Yayasan Obor Indonesia.

Baubock, R., \& Faist, T. (2010).

Diaspora and

Transnationalism:

concepts, theories, and

methods. Amsterdam:

Amsterdam Univesity

Press.

Kementerian Luar Negeri Republik

Indonesia. (2019,

September 9). Menteri

Luar Negeri Minta

Perwakilan RI terus

Perjuangkan

Kepentingan Ekonomi

Indonesia. Retrieved

from Kementerian Luar
Negeri Republik

Indonesia:

https://kemlu.go.id/porta

1/id/read/581/berita/ment

eri-luar-negeri-minta-

perwakilan-ri-terus-

perjuangkan-

kepentingan-ekonomi-

indonesia

liputan6.com. (2019, Januari 21). Kisah

Diaspora Indonesia

Sukses Berbisnis Bumbu

Rendang di Amerika

serikat. Retrieved from

liputan6Liputan6.com/lifestyle/read/387

6351/kisah-diaspora-

indonesia-sukses-

berbisnis-bumbu-

rendang-di-amerika-

serikat.

Kementerian Budaya dan

Pariwisata. (2018,

Oktober 9). Berapa

Pendapatan Devisa dari

Sektor Pariwisata

Indonesia? Retrieved

Oktober 15, 2019, from

databooks:

https://databoks.katadata

.co.id/datapublish/2018/ 
09/10/berapa-

pendapatan-devisa-dari-

sektor-pariwisata-

indonesia

Kusumawardhana \&

Bhardanshah. (2018).

\section{Polirateral}

Gastrodiplomasi:

Mengungkap Interaksi

Antar Aktor Dalam

Aktivitas Gastrodiplomasi

Indonesia Di Los Angeles.

Jurnal Ilmu dan Budaya,

Vol. 41, No.61

Arief, Stefanus Setiaji.

Diaspora Indonesia,

Pendapatan warga

Indonesia lebih tinggi

daripada Warga Asli.

(Online) Available at:

https://ekonomi.bisnis.com/

$\mathrm{read} / 20130819 / 9 / 157568 / \mathrm{di}$

aspora- indonesia-

pendapatan-wni-di-as-

lebih-tinggi-ketimbang-

warga-asli. (Accesseed 14

September 2019)

Wicaksana, Rendy dkk.

Konvensi Indonesian

Diaspora Network USA di
Chicago. (Online)

Available at:

https://www.voaindonesia.c

om/a/konvensi-indonesian-

diaspora-network-usa-di-

chicago-

illinois/4475553.html.

(Accessed 14 September

2019). 